\title{
SOME IMPORTANT CHEMICAL AND AROMA CHARACTERISTICS OF SOME NEW PEPPER CULTIVARS (Capsicum annuum L CV A30706 F1, Capsicum annuum L CV KILÇIK F1, Capsicum annuUm L CV BITTER F1)
}

\author{
Tolga SARIYER ${ }^{1 *}$, Mehmet Ali GÜNDOĞDU ${ }^{1}$, Arda AKÇAL ${ }^{1}$, Murat ŞEKER $^{1}$ \\ ${ }^{1}$ Çanakkale Onsekiz Mart University, Faculty of Agriculture, Department of Horticulture, 17020, Çanakkale, Turkey
}

\begin{abstract}
Obtaining agricultural products with better quality is closely related to the development of new cultivars. New cultivars are increasing gradually internationally as a result of the breeding programs. Capsicum annuum L. 'A30706 F1', Capsicum annuum L. 'Kılçı F1', Capsicum annuum L. 'Bitter F1' pepper cultivars are newly developed registered pepper cultivars in Turkey. A30706 F1 is a bitter and black coloured long pepper also called purple coloured, Kılçı F1 is a sweet long thin pepper and Bitter F1 is a hot long thin pepper. Among the cultivars while the highest amount of ascorbic acid $(216.35 \mathrm{mg} / 100 \mathrm{~g})$ was determined in A30706 F1, the highest amount of phenolic compounds (63.69 mg GAE/100g) was determined in the Bitter F1 cultivar. Hexanal was found as major aroma component in A30706 F1 and Kılçık F1 pepper cultivars, which creates a sensory perception as fresh, cut grass. Hexanal and E-2tetradecenal were found as major aroma components in Bitter F1 cultivar. E-2-tetradecenal creates a sensory perception as fatty, waxy, cheesy.
\end{abstract}

Keywords: Ascorbic acid, Pepper cultivars, Phenolic compounds, Volatile compounds

*Corresponding author: Çanakkale Onsekiz Mart University, Faculty of Agriculture, Department of Horticulture, 17020, Çanakkale, Turkey

E mail: tolgasariyer@comu.edu.tr (T. SARIYER)

Tolga SARIYER (iD) https://orcid.org/0000-0002-1844-2996

Mehmet Ali GÜNDOĞDU (iD) https://orcid.org/0000-0002-5802-5505

Arda AKÇAL (iD) https://orcid.org/0000-0002-0426-0745

Murat ŞEKER (iD) https://orcid.org/0000-0002-6886-0547

Received: November 18, 2021

Accepted: December 27, 2021

Published: April 01, 2022

Cite as: Sarıyer T, Gündoğdu MA, Akçal A, Şeker M. 2022. Some Important Chemical and Aroma Characteristics of Some New Pepper Cultivars (Capsicum annuum L cv A30706 F1, Capsicum annuum L cv Kılçık F1, Capsicum annuum L cv Bitter F1). BSJ Agri, 5(2): 72-79.

\section{Introduction}

Plants have the capacity to synthesize, accumulate and spread aroma and scent molecules. These are commercially important in food, pharmacy, agriculture, chemical industries in terms of flavorings, drugs, pesticides, industrial feed stocks (Schwab, 2008). These aroma and scent molecules are also found in pepper.

After Columbus came to Europe with pepper seeds, pepper spread around the world with the help of the Spanish and Portuguese trade routes. It also spread from Europe to Africa, India, China, Japan and Korea with the help of spice routes. An obelisk from the Chavin culture in Peru has a black caiman carving and in its claws are the pods of peppers (Bosland and Votava, 2012). Today, pepper has many uses such as spices, industry, pharmacy, fresh consumption, flavoring agents and insecticides.

Ascorbic acid is an important antioxidant and has a protective role in various diseases (Domitrovic, 2006) and it is an essential component in the prevention of scurvy disease. Soluble solids used in sugar content estimation is an important criterion in all fruits and vegetables. The total amount of phenolic compounds in plants is related to UV protective, signaling compound, pigment formation, plant growth, defense mechanism (Lattanzio et al., 2006) and taste factors such as bitterness. The aroma composition is used in the food and pharmaceutical industries to give taste and smell.

Kocsis et al. (2002) carried out a study to determine the aroma composition of 11 sweet (Capsicum annuum L. 'Kalocsai-M-622', 'Szegedi-20', 'Kalocsai-801', 'Szegedi80', 'Csa' rda' s', 'Folklo' r', 'Reme'ny, Rubin', 'Ka'rmin', 'Zuhatag', 'Miha' lyteleki') and 2 hot (Capsicum annuum L. 'Kalocsai-V-2' and 'Szegedi-178') Hungarian red pepper varieties. In the study (Kocsis et al. 2002) it was determined that hot varieties have more terpene, sesquiterpene and terpene derivative components than sweet varieties. Aroma and fragrance content of KalocsaiV-2 (hot) variety were richer than Kalocsai-M-622 (sweet) variety. In this case, it is especially important to determine the aroma characteristics of the A30706 F1 cultivar, which is a hot pepper cultivar.

The highest amount of flavorings were 4-metoksi-fenol (3.69 ppm), etil hekzadekanoat (3.64 ppm), hekzanal (1.22 ppm) and izopulegol (1.01 ppm) in green pepper (Capsicum annuum L.) in study conducted by Jang et al. (2008). 2-methoxy-3-isobtylpyrazine (similar to bell pepper scent), nona-trans,cis-2.6-dienal (similar to 
cucumber scent), deca-2.4-dienals (similar to fried chicken scent), limonene (similar to citrus scent), methyl salicylate (similar to oil of wintergreen) compounds were determined at high levels in California green bell pepper (Capsicum annuum var. grossum, 'Sendt') with vacuum isolation analyze however furfural, benzaldehyde, heptan-2-one, hex-cis-3-enol, hept-trans-3-en-2-one, methyl salicylate compounds were at high levels with water solution analyze (Buttery et al., 1969).

Major essential oils in two pepper varieties (Capsicum annuum L. 'Twingo', Capsicum annuum L. 'No.1') were found as Benzaldehyde 20.9\%), 2-Methoxy-3-isobutylpyrazine (20.4\%), Z-B-Ocimene (13\%), Dimethylbenzene (8.5\%), Heptane-2-one (8.0\%) in Twingo variety and as 2-Methoxy-3-isobutyl-pyrazine (12.7\%), Linalool (8.3\%), Z- $\beta$-Ocimene (6.2\%), Nona-trans,cis-2,6-dienal (6.2\%), Hexanal (5.6\%) in No.1 variety (El-Ghorab et al., 2013).

The water soluble dry matter amount of peppers were $5.8 \%$ in the first group varieties (Ilıca 256, Acıkıl, Çorbacı, Manisa Yeşili, Çetinel and Demre), it was 5.3\% in the second group varieties (table varieties consist of Çarliston, Kandil Dolma and industrial varieties consist of Üçburun, Yunan, Kale), it was $5.4 \%$ in third group varieties (California Wonder and Kapia) and forth group varieties (Jalepeno), it was $5.5 \%$ in fifth group varieties (use for pickle) and it was $5.1 \%$ in sixth group varieties (tomato pepper varieties) in study regarding morphological variability of some important pepper genotypes which were grown in Turkey (Duman and Düzyaman, 2004).

Sim and Sil (2008), determined the amount of phenolic substance in the pericarp of red pepper as $47.52 \mathrm{mg} / \mathrm{g}$ GAE in their study regarding antioxidant activities in the pericarp and seeds of red pepper (Capsicum annuum L.). Phenolic, peroxidase and capsidiol levels in sweet pepper (Capsicum annuum L. 'Almuden') were determined as between $20-40 \mathrm{mg} / 100 \mathrm{~g}$ in the green maturation period and $80-100 \mathrm{mg} / 100 \mathrm{~g}$ in the red maturation period (Amor et al., 2008).

The subject of the study is the evaluation of three new pepper cultivars (Capsicum annuum L. 'A30706 F1', Capsicum annuum L. 'Kılçık F1', Capsicum annuum L. 'Bitter F1') in terms of ascorbic acid, soluble solids, amount of phenolic compounds and flavor composition.

\section{Material and Methods}

In this study 'A30706 F1', 'Kılçık F1' and 'Bitter F1' pepper cultivars (Capsicum annuum L.) were used as plant materials. A30706 F1 is a bitter and black coloured long pepper, Kılçık F1 is a sweet long thin pepper, Bitter $\mathrm{F} 1$ is a hot long thin pepper. This research was carried out at the experimental fields of Çanakkale Onsekiz Mart University's Faculty of Agriculture in Turkey in 2019.

\subsection{Analyzing of Aroma Compounds in Pepper Cultivars}

Aroma analyzes were performed using Shimadzu QP2010 Plus Gas Chromatography-Mass Spectrometer system located in Çanakkale Onsekiz Mart University,
Faculty of Agriculture, Department of Horticulture.

Methods reported by Vichi et al. (2007), Sabatini and Marsilio (2008), Reboredo-Rodriguez et al. (2013), Ekinci et al. (2016) ve Bozok et al. (2018) were modified and used for the identification of aroma components in pepper samples. The step of preparing samples for the analysis were as follows: $50 \mathrm{~g}$ sample of mushroom purees obtained with homogenizer was treated with 100 $\mathrm{ml}$ diethyl ether solvent in erlenmayer and the solvent was concentrated to $1 \mathrm{ml}$ by centrifuge and concentrator. Operating conditions of GC / MS device are given below. Carrier gas; Helium, column; DB-WAX® polyethylene glycol (PEG) ( $30 \mathrm{~m}$ x $0.25 \mathrm{~mm} \times 0.25 \mu \mathrm{m}$ ), injection block temperature; $280^{\circ} \mathrm{C}$, linear flow; $41 \mathrm{~cm} / \mathrm{sec}$, pressure; $70.3 \mathrm{kPa}$, injection mode; split (1:50)

\subsection{Oven Temperature Program}

It was 1 minute at $40^{\circ} \mathrm{C}$ at the beginning, then 2 minutes at $200{ }^{\circ} \mathrm{C}$ with a speed of $4{ }^{\circ} \mathrm{C} / \mathrm{min}$ and 10 minutes at 250 ${ }^{\circ} \mathrm{C}$ with a speed of $10{ }^{\circ} \mathrm{C} / \mathrm{min}$. Time of total analysis was 58 minutes. Detector; mass spectrometer (MS), library; Nist and Wiley, ion temperature; $250{ }^{\circ} \mathrm{C}$, interfacial temperature: $230{ }^{\circ} \mathrm{C}$, solvent cut time; $4 \mathrm{~min}$, scanned mass range and scanning speed; 40-350 amu (m/z) and $666 \mathrm{amu} / \mathrm{sec}$, ionization energy; $70 \mathrm{eV}$

2.3. Analyzing of Total Phenolics (mg GAE/100g) in Pepper Cultivars

Fruit juice ( $5 \mathrm{~g}$ ) was supplemented with $5 \mathrm{ml}$ methanol and centrifuged at $4000 \mathrm{rpm}$ for 10 minutes. The samples were then supplemented with $2.5 \mathrm{ml} 10 \%$ Folin-Ciocalteu and $2 \mathrm{ml} 1 \mathrm{M} \mathrm{Na} 2 \mathrm{CO} 3$ and kept in water bath at $45^{\circ} \mathrm{C}$ for 15 minutes. Samples were taken to Shimadzu UV-VIS spectrophotometer (UV-Vis Spectrophotometer, Shimadzu Corporation, Tokyo-Japan) and read at $765 \mathrm{~nm}$ absorbance value against 10\% Folin-Ciocalteu. Results were expressed in total gallic acid equivalent (GAE) $\mathrm{mg} / 100 \mathrm{~g}$ (Zheng and Wang, 2001).

\subsection{Analyzing of Soluble Solids Content (\%) in Pepper Cultivars}

It was determined by measuring soluble solids content of fruit juices with using digital hand refractometer in marketable 36 fruits.

\subsection{Analyzing of $\mathrm{pH}$ Value and Titratable Total Acidity (g/100g) in Pepper Cultivars}

Amount of $\mathrm{NaOH}(0.1 \mathrm{~N})$ that was spent when $\mathrm{pH}$ value was 8.1 was determined by using burette and WTW digital desktop $\mathrm{pH}$ meter. The amount of titratable acidity (g/100g) was calculated in terms of citric acid by formula (International Federation of Fruit Juice Producers, 1968). 2.6. Analyzing of Ascorbic Acid Content (mg/100g) in Pepper Cultivars

It was determined by method of Pearson and Churchill (1970) with using Shimadzu UV-VIS -1800 spectrophotometer. $175 \mathrm{ml}$ of $0.4 \%$ Oxalic Acid was supplemented to $25 \mathrm{~g}$ fruit pulp and samples were filtered from Whatmann (No: 2) filter paper for ten minutes. L1 value was determined by reading of Oxalic acid/2.6 Diclorophenol indophenol: 1/10 solution in response to Oxalic acid/Pure water: $1 / 10$ solution at 520 
transmittance value. L2 value was determined by reading of filtered sample/2.6 Diclorophenol indophenol: 1/10: solution in response to Oxalic acid/Pure water: 1/10 solution at 520 transmittance value. In this way, ascorbic acid content was calculated by using the formulation.

\subsection{Trial Design and Statistical Analysis of the} Experiment

Experiment was set up based on completely randomised design with 3 replications consist of 30 plants in each replication in Çanakkale Onsekiz Mart University Dardanos farm which is located in Çanakkale Onsekiz Mart University Faculty of Agriculture. Seedlings planted with a distance of 0.33 meters within the row and 1 meter between the rows.

Samples were selected from 10 marked plants for each replication as 5 samples from each plant. A total of 50 peppers for each replication were crushed in a blender and stored until analyzed in a refrigerator at Çanakkale Onsekiz Mart University Faculty of Agriculture, Horticulture Laboratory, which can cool down to $-80^{\circ} \mathrm{C}$. For the vitamin $\mathrm{C}$ readings, samples were treated with $0.4 \%$ oxalic acid and stored in a refrigerator at $+4^{\circ} \mathrm{C}$ until the analysis.

Before the experiment, soil samples were taken from ten different regions of the trial land at a depth $(0-30 \mathrm{~cm})$ that would represent the active root zone by simple random sampling method, representing the whole of the field (Crepin and Johnson, 1993) and fertilization was performed according to the results of the soil analysis. Irrigation was applied for every three days with using a drip irrigation system.

In the experiment, analysis of variance was performed using the SAS.8.0. computer package program for statistical analysis and LSD $(\mathrm{P}<0.05)$ test was used to compare the differences between the means of the data.

Biplot analysis was used to interpret the data of different aroma components in the aroma composition and the data were evaluated on the graph.

In the study, it was determined that the sum of PC1 (57\%) and PC2 (43\%) values in the biplot graph was $100 \%$. It was decided that biplot analysis would be useful in terms of the visual advantage it provides in evaluating the variation of different aroma components according to the subjects. Biplot is a useful tool in information analysis and provides visual evaluation in large information matrices. Biplot can show distances between units and it can group units (Gabriel, 1971). Aroma compounds with major importance were included besides compounds which exist in all three cultivars in the biplot graph.

\section{Results and Discussion}

In the study, no significant difference was found $(\mathrm{P}<0.05)$ between the cultivars in terms of $\mathrm{pH}$ and soluble solids values. The titratable acidty values were found to be similar in Bitter F1 and Kılçı F1 cultivars and lower than A30706 F1 cultivar as shown in Table 1.
Table 1. The $\mathrm{pH}$, titratable acidity, soluble solids values of pepper cultivars

\begin{tabular}{lccc}
\hline & $\mathrm{pH}^{\mathrm{a}}$ & $\begin{array}{c}\text { Titratable } \\
\text { Acidity } \\
(\mathrm{g} / 100 \mathrm{~g})^{\mathrm{a}}\end{array}$ & $\begin{array}{c}\text { Soluble } \\
\text { Solids }(\%)^{\mathrm{a}}\end{array}$ \\
\hline A30706 F1b & 6.6 & $0.100^{\mathrm{A}}$ & 5.43 \\
Bitter F1 $^{\mathrm{b}}$ & 6.98 & $0.076^{\mathrm{B}}$ & 5.33 \\
Kılçık F1 & 6.9 & $0.073^{\mathrm{B}}$ & 5.83 \\
LSD P<0.05 & $\mathrm{NS}$ & 0.023 & $\mathrm{NS}$ \\
\hline
\end{tabular}

ABDifferent letters in same column shows the statistical difference,, aSoluble solids (\%) values, $\mathrm{pH}$, titratable acidity (g/100g), bepper cultivars.

In the study examining the chemical properties of two Spanish pepper varieties (Capsicum annuum L. 'Fresno de la Vega', Capsicum annuum L. 'Benavente-Los Valles') at different maturity stages, the soluble solids, $\mathrm{pH}$ values were determined as 6.93, 4.98 in 'FresnodlaVega' and 6.73, 4.79 in 'BenaventeLos' (Bernardo et al., 2008).

Balkaya et al. (2009) determined the amount of water soluble dry matter between $5.2-8.0 \%$ when all populations were evaluated in their study on red conic pepper (Capsicum annuum 'Conoides Mill.') genotypes.

Soluble solids, titratable acidity (\% citric asit) and $\mathrm{pH}$ contents of 'Arnoia' pepper variety were determined as $7 \%, 0.11,4.6(\mathrm{~g} / 100 \mathrm{~g})$ respectively in red maturity stage (Martinez et al., 2007)

Phenolic compounds which related to taste properties such as bitterness were found similar in A30706 F1 and Kılçık F1 cultivars and lower than Bitter F1 cultivar when evaluated statistically $(\mathrm{P}<0.05)$. Ascorbic acid (vitamin $\mathrm{C})$ values were statistically different $(\mathrm{P}<0.05)$ and the highest value was obtained in the A30706 F1 cultivar, followed by the ascorbic acid values of the Bitter F1 and Kılçık F1 cultivars, respectively as indicated in Table 2.

Table 2. The phenolic compounds and ascorbic acid values of pepper cultivars

\begin{tabular}{lcc}
\hline & $\begin{array}{c}\text { Phenolic } \\
\text { Compounds }(\mathrm{mg} \\
\text { GAE/100g) }\end{array}$ & $\begin{array}{c}\text { Ascorbic Acid } \\
(\mathrm{mg} / 100 \mathrm{~g})^{\mathrm{a}}\end{array}$ \\
\hline A30706 F1 $^{\mathrm{b}}$ & $47.72^{\mathrm{B}}$ & $216.35^{\mathrm{A}}$ \\
Bitter F1 $^{\mathrm{b}}$ & $63.69^{\mathrm{A}}$ & $205.20^{\mathrm{AB}}$ \\
Kılçlk F1 $^{\mathrm{b}}$ & $50.21^{\mathrm{B}}$ & $194.87^{\mathrm{B}}$ \\
LSD P $<0.05^{\mathrm{B}}$ & 58.85 & 21.45 \\
\hline
\end{tabular}

ABDifferent letters in same column shows the statistical difference, aPhenolic Compounds (mg GAE/100g), Ascorbic Acid $(\mathrm{mg} / 100 \mathrm{~g})$ values, ${ }^{\mathrm{b}}$ Pepper cultivars.

The amount of ascorbic acid was determined between $64.9-15.2 \mathrm{mg} / 100 \mathrm{~g}$ in the varieties (Capsicum annuum L. '730 F1', '1245 F1', 'Amazon F1', 'Serademre 8', 'Kusak 295 F1') examined in the study by Topuz and Ozdemir (2007), it was determined as $202.1 \mathrm{mg} / 100 \mathrm{~g}$ in the cultivar (Capsicum annuum L. 'Caryca F1') examined in another study (Buckowska et al., 2016). Balkaya and Karaağaç (2009) determined ascorbic acid content between 53.0-155.0 mg/100g in red conical pepper 


\section{Black Sea Journal of Agriculture}

genotypes (Capsicum annuum L. 'conoides Mill.') when all populations were evaluated.

Phenolic contents were found between $607-2724 \mathrm{mg} / \mathrm{kg}$ in study which include 29 pepper varieties grown in Turkey (Frary et al., 2008). Kolton et al. (2011) determined the amount of phenolic substance in sweet pepper (Capsicum annuum L. 'Spartacus') as 35.77 in the green maturity period and $56.44 \mathrm{mg} / 100 \mathrm{~g}$ in the red maturity period.
3.1. Comparison of Pepper Cultivars $(P<0.05)$ in terms of Aroma Components

It was determined that there was a significant difference $(\mathrm{P}<0.05)$ between aroma components.

The major aroma components were determined as hexanal in aldehydes (Table 3), hexanol in alcohols (Table 4), methyl salicylate in esters (Table 5), $\gamma$ muurolen in terpenes (Table 6).

Table 3. Comparison of pepper cultivars in terms of aldehyde group aroma compounds

\begin{tabular}{lcccc}
\hline Aroma Compounds $^{\mathrm{a}}$ & A30706 F1 & Bitter F1 & Kllçılk F1 $^{\mathrm{b}}$ & LSD P<0.05 \\
\hline Hexanal & $26.36^{\mathrm{A}}$ & $14.50^{\mathrm{C}}$ & $18.85^{\mathrm{B}}$ & 4.0914 \\
E-2-tetradecenal & 14.76 & 14.42 & 12.52 & N.I. \\
3-Phenyl butanal & $4.31^{\mathrm{AB}}$ & $2.80^{\mathrm{B}}$ & $5.20^{\mathrm{A}}$ & 2.2898 \\
Benzaldehyde & $2.37^{\mathrm{A}}$ & $0.64^{\mathrm{B}}$ & $0^{\mathrm{C}}$ & 0.1888 \\
E-2-Hexenal & $1.42^{\mathrm{A}}$ & $0.76^{\mathrm{B}}$ & $0^{\mathrm{C}}$ & 0.2553 \\
E-2-Heptenal & $1.46^{\mathrm{A}}$ & $0.64^{\mathrm{B}}$ & $0^{\mathrm{C}}$ & 0.2584 \\
2-Pentyl-2-nonenal & 0 & 0.49 & 0 & NS \\
Toplam Aldehyde (\%) & 50.68 & 34.24 & 36.57 & \\
\hline
\end{tabular}

aAroma compounds, bPepper cultivars, NS= non-significant

Table 4. Comparison of pepper cultivars in terms of alcohol group aroma compounds

\begin{tabular}{lcccc}
\hline Aroma Compounds $^{\mathrm{a}}$ & A30706 F1 & Bitter F1 $^{\mathrm{b}}$ & Kllçı F1 $^{\mathrm{b}}$ & LSD P<0.05 $^{\mathrm{b}}$ \\
\hline Hexanol & $10.3^{\mathrm{A}}$ & $6.74^{\mathrm{B}}$ & $11.43^{\mathrm{A}}$ & 3.4049 \\
Z-3-Hexenol & 2.19 & 1.42 & 2.44 & NS \\
Heptanol & $1.55^{\mathrm{C}}$ & $3.93^{\mathrm{B}}$ & $6.65^{\mathrm{A}}$ & 1.9458 \\
2-Desycloxy Ethanol & $2.32^{\mathrm{B}}$ & $3.74^{\mathrm{A}}$ & $1.61^{\mathrm{B}}$ & 0.8266 \\
E-2-Hexenol & $4.83^{\mathrm{A}}$ & $0.70^{\mathrm{B}}$ & $0^{\mathrm{C}}$ & 0.3065 \\
Isohexanol & 0 & 0.78 & 0 & \\
3-methyl-3-butenol & 0 & 0.92 & 0 & \\
Total Alcohol (\%) & 21.62 & 18.23 & 22.13 &
\end{tabular}

ABDifferent letters in same column shows the statistical difference, aAroma compounds, bPepper cultivars.

Table 5. Comparison of pepper cultivars in terms of ester group aroma compounds

\begin{tabular}{lcccc}
\hline Aroma Compounds $^{\mathrm{a}}$ & A30706 F1 & Bitter F1 & Klçlk F1 & LSD P<0.05 \\
\hline Methyl salicylate & $5.89 \mathrm{~A}$ & $5.05^{\mathrm{A}}$ & $10.43^{\mathrm{B}}$ & 0.8537 \\
Hexyl 2 methyl butyrate & $3.81^{\mathrm{A}}$ & $2.44^{\mathrm{B}}$ & $4.49^{\mathrm{A}}$ & 0.8711 \\
Ethyl Hexadecanoate & $1.89^{\mathrm{B}}$ & $6.01^{\mathrm{A}}$ & $5.51^{\mathrm{A}}$ & 1.6278 \\
2-Ethyl-3-Hydroxyhexyl butyrate & $0^{\mathrm{B}}$ & $1.29^{\mathrm{A}}$ & $1.40^{\mathrm{A}}$ & 0.4401 \\
2,2-Dimethyl-1,3-propanediol isobutanate & $0^{\mathrm{B}}$ & $0.60^{\mathrm{A}}$ & $0.81^{\mathrm{A}}$ & 0.4377 \\
Hexyl iso butyrate & 0 & 0.91 & 0 & \\
Ethyl decanoate & 0 & 0.74 & 0 & \\
Butyl iso butyrate & 0 & 0.99 & 0 & \\
Hexyl hexanoate & 0 & 2.10 & 0 & \\
Isobutyl isopentanoate & 0 & 0.82 & 0 & \\
Methyl tert-butylacetate & 0 & 1.57 & 0 \\
Total Ester (\%) & 11.59 & 22.51 & 22.64 \\
\hline
\end{tabular}

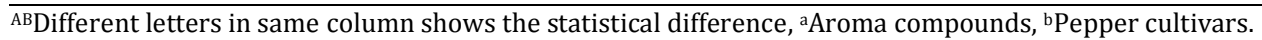

Table 6. Comparison of pepper cultivars in terms of terpene group aroma components

\begin{tabular}{lcccc}
\hline Compound $^{\mathrm{a}}$ & A30706 F1 & Bitter F1 & Kilçlk F1 & LSD P<0.05 \\
\hline$\gamma$-Muurolen & $5.12^{\mathrm{A}}$ & $4.88^{\mathrm{A}}$ & $2.38^{\mathrm{B}}$ & 1.8278 \\
Z-Linalool oxide & 1.46 & 2.68 & 2.46 & N.I. \\
Total Terpene (\%) & 6.58 & 7.57 & 4.84 & \\
\hline
\end{tabular}

ABDifferent letters in same column shows the statistical difference, aAroma compounds, bPepper cultivars. 


\section{Black Sea Journal of Agriculture}

A total of 20 aroma components from 5 component groups were detected in 'A30706 F1' pepper cultivar. In the first group consisting of aldehydes, there were 6 aldehyde components (Table 3). The second group consisting of alcohols included 5 alcohol components
(Table 4). In the third group consisting of esters, there are 3 ester components (Table 5). In the fourth group consisting of terpenes, there were 2 terpene components (Table 6). In the other components group, there were 4 components (Table 7).

Table 7. Comparison of pepper cultivars in terms of other group aroma components

\begin{tabular}{lcccc}
\hline Compound $^{\mathrm{a}}$ & $\mathrm{A} 30706 \mathrm{~F} 1^{\mathrm{b}}$ & Bitter F1 $^{\mathrm{b}}$ & Kılçık F1 & LSD P<0.05 \\
\hline Isobutyl methoxy pyrazine & $2.34^{\mathrm{B}}$ & $2.4^{\mathrm{AB}}$ & $3.22^{\mathrm{A}}$ & 0.6062 \\
Hexanoic acid (Caproic acid) & 2.26 & 2.23 & 1.91 & $\mathrm{NS}$ \\
Pentadecane & $2.89^{\mathrm{C}}$ & $6.15^{\mathrm{A}}$ & $4.80^{\mathrm{B}}$ & 0.4766 \\
Hexadecane & $2.04^{\mathrm{B}}$ & $4.35^{\mathrm{A}}$ & $2.31^{\mathrm{B}}$ & 1.3584 \\
Dodecan & 0 & 0.86 & 0 & 0.4661 \\
2-methyl butanoic acid & $0 \mathrm{~B}$ & $1.13^{\mathrm{A}}$ & $1.58^{\mathrm{A}}$ & 13.82 \\
Total Other Components (\%) & 9.53 & 17.46 & 2 & \\
\hline
\end{tabular}

ABDifferent letters in same column shows the statistical difference, aAroma compounds, ${ }^{\mathrm{b}}$ Pepper cultivars.

A total of 33 aroma components from 5 component groups were detected in 'Bitter F1' pepper cultivar. In the first group consisting of aldehydes, there were 7 aldehyde components (Table 3). The second group consisting of alcohols included 7 alcohol components (Table 4). The third group consisting of esters included 11 ester components (Table 5). In the fourth group consisting of terpenes, there were 2 terpene components (Table 6). In the other compounds group, there were 6 compounds.

A total of 19 aroma components from 5 component groups were detected in 'Kılçık F1' pepper cultivar. In the first group consisting of aldehydes, there were 3 aldehyde components (Table 3). The second group consisting of alcohols included 4 alcohol components (Table 4). In the third group consisting of esters, there were 5 ester components (Table 5). In the fourth group consisting of terpenes, there were 2 terpene components (Table 6). In the other compounds group, there were 5 compounds.

Aldehyde components were composed the major content in the aroma profile of all pepper cultivars. Among the aldehydes, hexanal was determined as the main aldehyde component in A30706 F1 and Kılçı F1 pepper cultivars. Hexanal and E-2-tetradecenal were the main aldehyde components in Bitter F1 pepper cultivar (Table 3). In a study (Ziino et al., 2009) conducted on different pepper varieties, hexanal was found as second major aldehyde component.

It was reported that hexanal component creates a fresh, cut grass sensory perception (Selli et al., 2014) and odor description of E-2-tetradecenal was specified as fatty, waxy, cheesy in study by Yüksel et al. (1998).

It was seen that aldehyde group aroma components were statistically significantly different $(\mathrm{P}<0.05)$ among the cultivars as stated in Table 3 . The highest ratio of hexanal and 3-Phenyl butanal components was determined in A30706 F1 cultivar, followed by Kılçık F1 and Bitter F1 cultivars, respectively. There was no statistical difference
$(\mathrm{P}<0.05)$ between the cultivars in terms of $\mathrm{E}-2$ tetradecenal component.

Hexanol was the main alcohol component in all pepper cultivars ('A30706 F1', 'Kılçık F1', 'Bitter F1') (Table 4).

Hexanol creates a mint and green grass sensory perception (Calin Sanchez et al., 2010).

According to statistical results $(\mathrm{P}<0.05)$ concerning alcohol group aroma components as mentioned in Table 4, it was determined that A30706 F1 and Kılçık F1 cultivars were similar in terms of hexanol component. The lowest hexanol ratio was determined in Bitter F1 cultivar. A30706 F1 and Kılçık F1 cultivars were found to be similar and lower than Bitter F1 in terms of 2Desycloxy Ethanol component ratio. The highest ratio in heptanol component was determined in Kılçık F1 cultivar, followed by Bitter F1 and A30706 F1 cultivars, respectively. It has been reported that the heptanol component produces a musty, sweet, woody sensory perception (Feng et al., 2019). There was no statistical $(\mathrm{P}<0.05)$ difference between the cultivars in terms of Z-3Hexenol component.

When the aroma components of the ester group were evaluated, it was determined that methyl salicylate component was the major component in all cultivars (Table 5).

It was determined that methyl salicylate caused peppermint (Niu et al., 2019) and oil of wintergreen (Buttery et al., 1969) sensory description. It was stated that hexyl 2-methyl butyrate has apple, grape fruit taste (Qin et al., 2017) and ethyl hexadecanoate component created soapy and oily sensory perception (Ding et al., 2015), respectively.

The ester group aroma contents of cultivars were significantly different $(\mathrm{P}<0.05)$ between cultivars as shown in Table 5. It was observed that the highest methyl salicylate ratio was in Kılçık F1 cultivar. It has been determined that the A30706 F1 and Bitter F1 cultivars have similar proportions of methyl salicylate component. It was determined that Hexyl 2 methyl butyrate 


\section{Black Sea Journal of Agriculture}

component was found in highest value in Kılçlk F1 cultivar, followed by A30706 F1 and Bitter F1 cultivars, respectively. In terms of Ethyl Hexadecanoate component, Kılçılk F1 and Bitter F1 cultivars were found to be similar and higher than A30706 F1 when evaluated statistically $(\mathrm{P}<0.05) \cdot \gamma$-Muurolen was determined as the main terpene component in A30706 F1 and Bitter F1 pepper cultivars (Table 6).

In the study carried out by Ziino et al. (2009) in fresh hot peppers (Capsicum annuum L.), it was reported that $\gamma$ muurolen, which is the major aroma component in the terpene group causes smell of herb, wood, spice (Ziino et al., 2009). Z-Linalool oxide component was determined as well as $\gamma$-Muurolen component in all pepper cultivars. The aroma of Z-Linalool oxide were described as floral, murici (Ferreira et al., 2016). Murici (Byrsonima crassifolia L., Malpighiaceae) is a fruit with a strong fruity and rancid cheese aroma (Rezende and Fraga, 2003).

Terpene group aroma components evaluated statistically $(\mathrm{P}<0.05)$ in Table 6. It was determined that A30706 F1 and Bitter F1 cultivars were similar in terms of $\gamma$ Muurolen component. The lowest $\gamma$-Muurolen ratio was determined in Kılçık F1 cultivar. There was no difference in terms of Z-Linalool oxide component between cultivars.
Among the other aroma components, pentadecane was determined as the main component in all ('A30706 F1', 'Kılçık F1', 'Bitter F1') pepper cultivars (Table 7). Pentadecane causes waxy sensory perception and was determined in pepper in various studies (Liu et al., 2010; Cirlini et al., 2019). Isobutyl methoxy pyrazine was determined as second main component in A30706 F1 and Kılçık F1 pepper cultivars. It creates sensory perception as green pepper. The hexanoic acid component, a 6-carbon saturated acid, is also known as caproic acid and generally causes sensory perception as sour, fatty, cheesy and sweat-like.

According to statistical results $(\mathrm{P}<0,05)$ concerning other aroma components as shown in Table 7 , the highest ratio of Isobutyl methoxy pyrazine aroma component was obtained in Kılçık F1 cultivar, followed by Bitter F1 and A30706 F1, respectively. It was observed that the Pentadecane component was similar in Kılçık F1 and BitterF1 cultivars and higher than A30706F1. The highest hexadecane component ratio was determined in Bitter F1 cultivar. Similar ratios of hexadecane components were observed in A30706 F1 and Kılçlk F1 cultivars. Aldehyde, Alcohol, Ester, Terpene and other group aroma components are shown in different colors on the biplot graph (Figure 1).

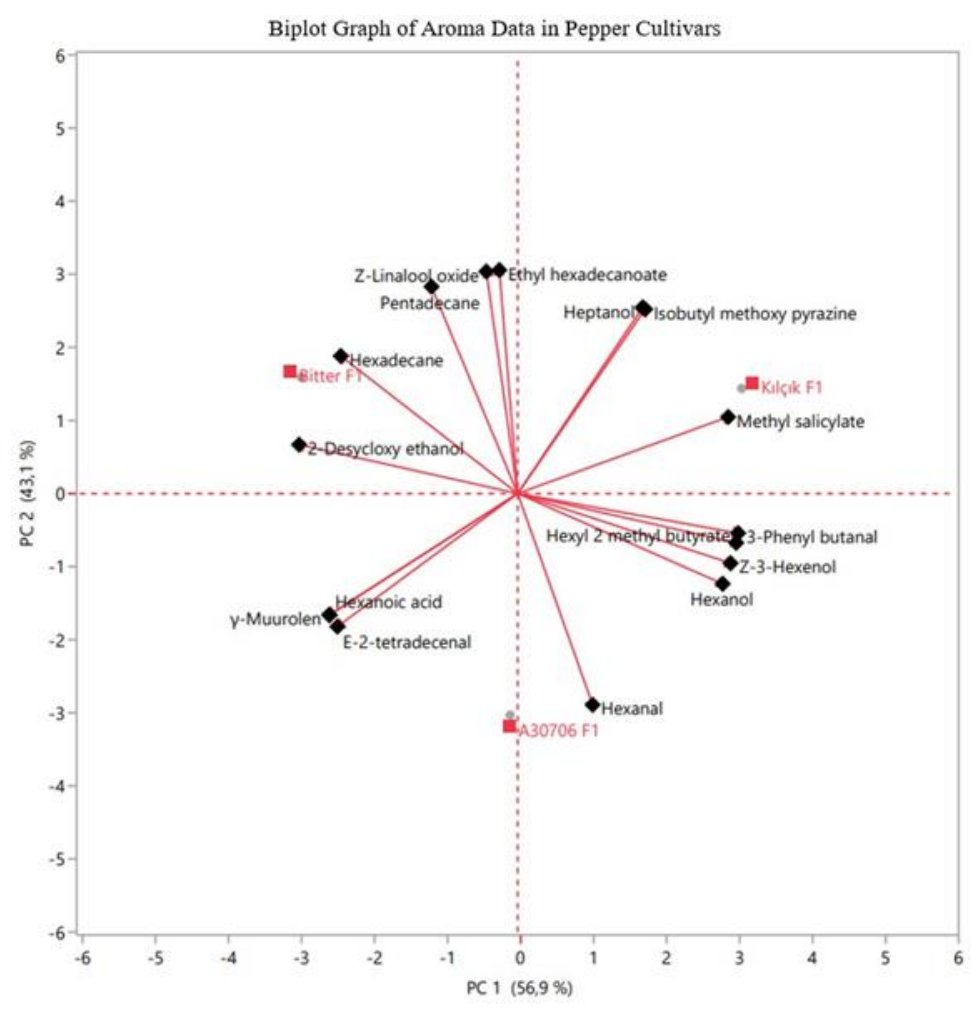

Figure 1. Biplot graph of aroma components according to pepper cultivars.

The fact that the E-2-tetradecenal, hexanoic acid, $\gamma$ muurolene compounds were in the same axis $(\mathrm{PC} 1<0$, PC2<0) only with the A30706 F1 cultivar showed that the A30706 F1 cultivar has higher values in terms of these compounds.

The fact that the hexanal compound was in positive axis with A30706 F1 cultivar $(\mathrm{PC} 2<0)$ and in negative axis with other cultivars and was in a closer location to A30706 F1 than other cultivars showed that this compound was higher in A30706 F1 than other cultivars. The presence of 2-decycloxyethanol, hexadecane, pentadecane, Z-linalooloxide, ethyl hexadecanoate compounds in the same axis $(\mathrm{PC}<0, \mathrm{PC} 2>0)$ with only the Bitter F1 cultivar showed that these compounds were 
found in higher rates in the Bitter F1 cultivar than other cultivars.

The presence of methyl salicylate, heptanol, isobutyl methoxy pyrazine compounds in the same axis (PC1 $>0$, PC2>0) with only the Kılçık F1 cultivar showed that these compounds were found in higher rates in the Kılçık F1 cultivar than other cultivars.

In the biplot graph; Hexanol, Z-3-hexenol, hexyl 2 methyl butyrate, 3-phenyl butanal compounds were found in positive direction (PC1>0) with Klç̧lk F1 cultivar and negative direction with other cultivars. At the same time, these compounds were located closer to Kılçık F1 cultivar than other cultivars. These two cases showed that the aforementioned compounds were found at higher rates in Kılçık F1 cultivar.

\section{Conclusion}

In the study, it was determined that the highest amount of ascorbic acid and titratable acidity was in the A30706 F1 cultivar (Table 1, Table 2). Ascorbic acid is a vitamin that the human body cannot produce, and pepper is known to be an important source of vitamin C. It is known that health problems such as scurvy disease and weakening of the immune system are seen in ascorbic acid deficiency.

It is seen that all three pepper cultivars in the study have a substantial amount of ascorbic acid. It was observed that the highest amount of phenolic compound was in Bitter F1 cultivar (Table 2). It is known that phenolic compounds give fruits and vegetables their peculiar bitter taste, odor and color. No significant differences $(\mathrm{P}<0.05)$ were found among the pepper cultivars in the study in terms of soluble solids and $\mathrm{pH}$ values.

It has been observed that Hexanal, E-2-tetradecenal, Hexanol, Methyl salicylate components were in major rate in the aroma composition (Table 3, Table 4, Table 5). Aroma composition is important in terms of flavor and fragrance in sectors such as agriculture, food, pharmacy. The Hexanal component, which creates a sensory perception like fresh, cut grass has created a high rate $(\mathrm{P}<0.05)$ in A30706 F1 cultivar than other cultivars (Table 3).

E-2-tetradecenal component, which makes the perception of fatty, waxy, cheesy odor, was not significantly different between cultivars $(\mathrm{P}<0.05)$ but it was higher in A30706 F1 and Bitter F1, and lower in Kılçık F1 cultivar (Table 3). Hexanol compound, which gives mint and green grass scent, was statistically similar in A30706 F1 and Kılçık F1 cultivars $(\mathrm{P}<0.05)$. Hexanol compound was lower in Bitter F1 than other cultivars $(\mathrm{P}<0.05)$.

Methyl salicylate component can be synthesized from salicylic acid (Kalaivani et al., 2016) which is methyl ester of salicylic acid. Methyl salicylate makes sense of peppermint and oil of wintergreen sensory perception, was found statistically higher $(\mathrm{P}<0.05)$ in Kılçık F1 cultivar (Table 5), which is a sweet cultivar. Methyl salicylate was double times higher in Kılçık F1 cultivar than other cultivars.

The $\gamma$-muurolen component, which is not found in a major proportion in the aroma composition, causes herb, wood, spice sensory perception. Faustino et al. (2020), stated in his study that the $\gamma$-Muurolen compound was found in the essential oil nanoemulsion of Protium heptaphyllum resin and could have a larvicidal effect on Aedes aegypti.

The high rates of $\gamma$-Muurolen in bitter varieties A30706 F1 and Bitter F1 compared to Kılçık F1, which is a sweet variety, may be a reason for the self-protection mechanism of bitter varieties.

\section{Author Contributions}

TS; initiated the research idea, set up the experiment, grown the seedlings, irrigated, fertilized the plants, suggested the research methods. MAG; organized the aroma components, suggested the research methods. MŞ; supervised the research. AA; structured the paper, suggested the research methods. All authors reviewed and approved the manuscript.

\section{Conflict of Interest}

The author declared that there is no conflict of interest.

\section{Acknowledgments}

This study was supported by the Scientific Research Projects Coordination Unit of Çanakkale Onsekiz Mart University. Project Number: FHD-2019-3091.

\section{References}

Amor FM, Serrano-Martinez A, Fortea I, Nunez Delicado E. 2008. Differential effect of organic cultivation on the levels of phenolics, peroxidase and capsidiol in sweet peppers. J Sci Food Agric, 88: 770-777.

Balkaya A, Karaağaç 0. 2009. Evaluation and selection of suitable red pepper (Capsicum annuum var. conoides Mill.) types in Turkey. Asian J Plant Sci, 8(7): 483-488.

Bernardo A, Martinez S, Alvarez M, Fernandez A, Lopez M. 2008. The composition of two Spanish pepper varieties (Fresno de la vega and Benavente-los valles) in different ripening stages. J Food Qual, 31: 701-716.

Bosland PW, Votava EJ. 2012. Domestication, history and spread. Ethnobotany. Chapter 1. Peppers vegetable and spice capsicums 2nd Edition. Crop Production Science and Horticulture Series 22. CPI Group Ltd, Croydon, UK, pp: 219.

Bozok F, Kafkas E, Büyükalaca S. 2018. Türkiye’nin Adana ilinden toplanan Suillus collinitus (Fr.)'un uçucu aroma kompozisyonunun belirlenmesi. Gida Bil Teknol Derg, 6(4): 486-489.

Buttery RG, Seifert RM, Guadagni DG, Ling LC. 1969. Characterization of some volatile constituents of bell peppers. J Agr Food Chem, 17(6): 1322-1327.

Calin Sanchez A, Martinez J, Vazquez Araujo L, Burlo F, Melgarejo P. Carbonell Barrachina A. 2010. Volatile composition and sensory quality of Spanish pomegranates (Punica granatum L.). J Sci Food Agric, 91: 586-592.

Cirlini M, Luzzini G, Morini E, Folloni S, Ranieri R, Dall'Asta C, Galaverna G. 2019. Evaluation of the volatile fraction, pungency and extractable color of different Italian Capsicum annuum cultivars designed for food industry. European Food 


\section{Black Sea Journal of Agriculture}

Res Techn, 245:2669-2678. DOI: 10.1007/s00217-01903378-x. 1-10.

Crepin J, Johnson RL. 1993. Soil sampling for environmental assessment. ACRC Press Company, New York, US, pp: 823.

Ding X, Wu C, Huang J, Zhou R. 2015. Changes in volatile compounds of Chinese luzhou-flavor liquor during the fermentation and distillation process. J Food Sci, 80(11): 2373-2381.

Domitrovic R. 2006. Vitamin C in disease prevention and therapy. Biochemia Medica, 16(2): 89-228.

Duman İ, Düzyaman E. 2004. Türkiye'de yetiştirilen bazı önemli biber genotiplerinin morfolojik variyabilitesi üzerinde bir araştırma. Ege Üniv Zir Fak Derg, 41(3): 55-66.

Ekinci N, Şeker M, Gündoğdu MA. 2016. Effects of post-harvest dippings of calcium oxide on aroma volatile compound of pink lady apple cultivar. Proceedings of the VII. Int. Sci. Agric. Sym. (Agrosym). pp: 1325-1331. 6-9 October 2016, Jahorina, Bosnia-Herzegovania.

El-Ghorab AH, Javed Q, Anjum FM, Hamed SF, Shaaban, HA. 2013. Pakistani bell pepper (Capsicum annum L.): chemical compositions and its antioxidant activity. Int J Food Prop, 16: 18-32.

Faustino CG, de Medeiros FA, Galardo AKR, Rodrigues ABL, Martins RL, de Medeiros Souza Lima Y, Tavares JF, de Medeiros MAA, dos Santos Cruz J, da Silva de Almeida SSM. 2020. Larvicide activity on aedes aegypti of essential oil nanoemulsion from the Protium heptaphyllum Resin. Molecules, 25: 5333. DOI: 10.3390/molecules25225333.1-12.

Feng T, Shui M, Song S, Zhuang H, Sun M, Yao L. 2019. Characterization of the key aroma compounds in three true varieties from china by flavoromics approach. Molecules, 24(3305): 1-17.

Ferreira DF, Garruti DDS, Barin JS, Cichoski AJ, Wagner R. 2016. Characterization of odor-active compounds in gabiroba fruits (Campomanesia xanthocarpa O. Berg). J Food Qual, 39: 90-97.

Frary A, Keçeli MA, Ökmen B, Şı̆gva HÖ, Yemenicioğlu A, Doğanlar A. 2008. Water-soluble antioxidant potential of Turkish pepper cultivars. Hort Sci, 43(3): 631-636.

Gabriel KR. 1971. The biplot graphic display of matrices with application to principal component analysis. Biometrika, 58(3): 453-467.

Jang HW, Ka MH, Lee KG. 2008. Antioxidant activity and characterization of volatile extracts of Capsicum annuum $\mathrm{L}$. and Allium spp. Flav Fragrance J, 23: 178-184.

Kalaivani K, Kalaiselvi MM, Senthil-Nathan S. 2016. Effect of methyl salicylate (MeSA), an elicitor on growth, physiology and pathology of resistant and susceptible rice varieties. Scient Rep, 6: 34498. DOI: 10.1038/srep34498.

Kocsis N, Amtmann M, Mednyanszky Z, Korany K. 2002. GC--MS investigation of the aroma compounds of Hungarian red paprika (Capsicum annuum) cultivars. J Food Comp Anal, 15: 195-203.

Kolton A, Wojciechowska R, Leja M. 2011. Effect of maturity stage and short-term storage on the biological quality of sweet pepper fruits. Veget Crops Res Bullet, 74: 143-152.

Lattanzio V, Lattanzio MTV, Cardinali A. 2006. Role of polyphenols in the resistance mechanisms of plants against fungal pathogens and insects. Phytochem Adv Res, 2006: 2367.
Liu R, Xiong K, Dai X, Wang L, Liu Z, Xue W. 2010. The effects of maturity on chilli pepper volatile components determined by SDE, GC-MS and HPLC. Nat Prod Commun, 5(6): 985-990.

Martinez S, Curros A, Bermudez J, Carballo J, Franco I. 2007. The composition of Arnoia peppers (Capsicum annuum L.) at different stages of maturity. Int J Food Sci Nutri, 58(2): 150161.

Niu Y, Wang P, Xiao Z, Zhu J, Sun X, Wang R. 2019. Evaluation of the perceptual interaction among ester aroma compounds in cherry wines By GC-MS, GC-O, odor threshold and sensory analysis: an insight at the molecular level. Food Chem, 275: 143-153.

Pearson D, Churchill AA. 1970. The chemical analyses of foods. Gloucester Place, 104: 233.

Qin L, Wer QP, Kang WH, Zhang Q, Sun J, Liu SZ. 2017. Comparison of volatile compounds in 'fuji' apples in the different regions in china. Food Sci Technol Res, 23(1): 79-89.

Reboredo-Rodriguez P, Gonzalez-Barreiro C, Cancho-Grande B, Simal-Gandara J. 2013. Aroma biogenesis and distribution between olive pulps and seeds with identification of aroma trends among cultivars. Food Chem, 141: 637-643.

Rezende CM, Fraga SRG. 2003. Chemical and aroma determination of the pulp and seeds of murici (Byrsonima crassifolia L.). J Braz Chem Soc, 14(3): 425-428.

Sabatini N, Marsilio M. 2008. Volatile compounds in table olives (Olea europaea L., Nocellara del Belice cultivar). Food Chem, 107: 1522-1528.

Schwab W, Davidovich-Rikanati R, Lewinsohn E. 2008. Biosynthesis of plant-derived flavor compounds. Plant J, 54: 712-732.

Selli S, Kelebek H, Ayseli MT, Tokbas H. 2014. Characterization of the most aroma-active compounds in cherry tomato by application of the aroma extract dilution analysis. Food Chem, 165: 540-546.

Sim KH, Sil HY. 2008. Antioxidant activities of red pepper (Capsicum annuum) pericarp and seed extracts. Int J Food Sci Technol, 43: 1813-1823.

Topuz A, Ozdemir F. 2007. Assessment of carotenoids, capsaicinoids and ascorbic acid composition of some selected pepper cultivars (Capsicum annuum L.) grown in Turkey. J Food Comp Anal, 20: 596-602.

URL1: http://worldcat.org/identities/lccn-n82101887 (access date: June 25, 2021).

Vichi S, Guadayol JM, Caixach J, López-Tamames E, Buxaderas S. 2007. Comparative study of different extraction techniques for the analysis of virgin olive oil aroma. Food Chem, 105: 1171-1178.

Yüksel L. 1998. Evaluation of the key odorants of fresh and dried coriander herb (Cilantro). MSc thesis, Mississippi State University, Faculty of Food Science and Technology, Mississippi, US, pp: 60.

Zheng W, Wang SY. 2001. Antioxidant activity and phenolic compounds in selected herbs. J Agric Food Chem, 49: 51655170 .

Ziino M, Condurso C, Romeo V, Tripodi G, Verzera A. 2009. Volatile compounds and capsaicinoid content of fresh hot peppers (Capsicum annuum L.) of different Calabrian varieties. J Sci Food Agric, 89: 774-780. 